\title{
Wind farm potential for electrical energy supply to a neighbourhood of single-family houses located at the Polish Baltic seaside
}

\author{
Marcin Zygmunt ${ }^{1, *}$, and Dariusz Gawin ${ }^{1}$ \\ ${ }^{1}$ Lodz University of Technology, Faculty of Civil Engineering, Architecture and Environmental \\ Engineering, Lodz, Poland
}

\begin{abstract}
The article presents an analysis for the Polish Baltic seaside concerning wind farm potential for producing electricity for housing. The analysis includes comparison of onshore and offshore wind climate parameters important for electrical energy production. The wind turbine parameters were assumed from the datasheet for two chosen turbines while the climate conditions for an onshore and an offshore location were set from the local measuring stations. For the purposes of this article, an energy model of a neighborhood of single-family houses was defined using Energy Plus software. Selection of house types was made following the present Polish statistics concerning newly constructed buildings. The electricity load duration curve of the neighborhood was carried out. Additionally, the analysis of electrical energy supply from wind farms for the analyzed location was performed. The analysis aim is assessment of the wind farm potential for covering energy needs of single family residential housing.
\end{abstract}

\section{Introduction}

The European Union (EU) has set a requirement with respect to energy and environmental impact in order to reach $20 \%$ of final energy consumption from renewable energy sources by year 2020 [1]. Moreover, the EU has set a long-term low carbon economy project called the 2050 energy strategy, assuming reduction of greenhouse gas emissions by $80-95 \%$, when compared to 1990 levels, by 2050 [2]. To achieve those goals there is a need for renewable energy sources (RES) use. In 2015 the renewable energy share of the total final energy consumption was too low - all renewables covered about $19.3 \%$ of the total global energy consumption. According to the electricity production data [3], wind power is the second most used energy source (after hydropower) in the renewable group (Fig. 1).

The wind energy resources vary considerably between climatic zones due to differences in terrain configuration and surface roughness. Wind climate conditions [4] at the Polish seaside are the most beneficial around the country (Fig. 2). Mean wind speed in Poland oscillates around $3.24 \mathrm{~m} / \mathrm{s}$ with overwhelming western (W, NW, SW) direction. According to [5], the legal regulations in Poland have introduced restrictions on the wind farms' location that limit the onshore wind Energy development in our country. It should be noted that the regulations do not apply to offshore wind farms.

* Corresponding author: marcin.zygmunt@p.lodz.pl 


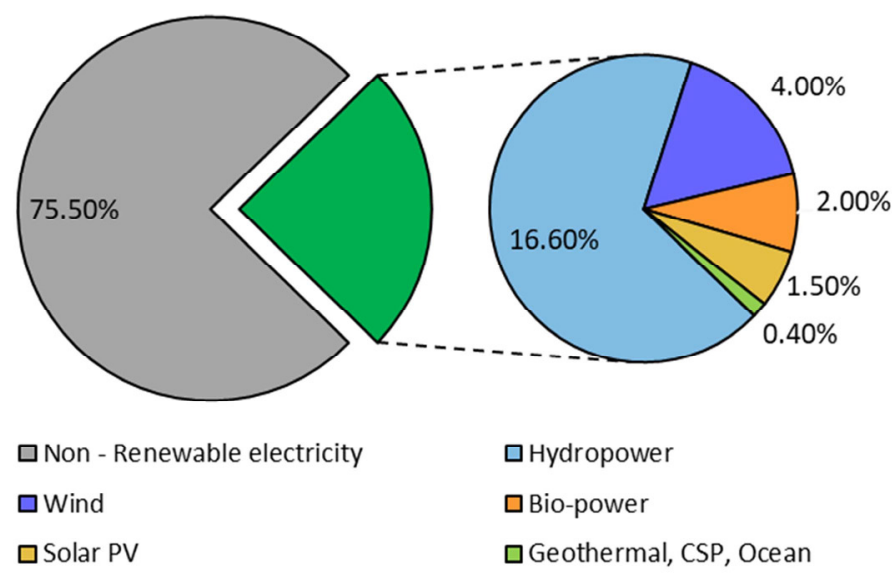

Fig. 1. Estimated renewable energy share of global electricity production, 2016 (source [3]).

The Baltic Sea is characterized by very good conditions for constructing offshore wind farms, however the wind energy resources are not known in much detail. First of all, the Baltic is a shallow sea with a $52.3 \mathrm{~m}$ average depth, so a foundation cost of planned offshore wind farm is much lower than e.g. in the Mediterranean (average depth 1,438 m). Even more important for usage of wind energy potential is the fact that offshore wind is much stronger than the onshore one. In general, the available wind energy is greater and more stable offshore than on the seaside [6]. Several Baltic countries (e.g. Denmark, Sweden, Germany) already have installed offshore wind farms while other countries (Poland included) have plans to do so [7].

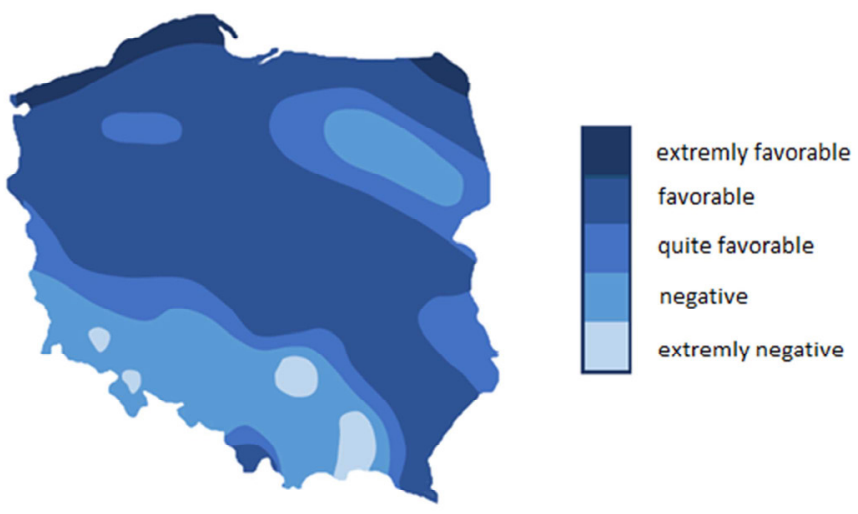

Fig. 2. Polish wind climate conditions map (source [4]).

The Polish single-family housing, constituting approx. 90\% of total residential buildings [8], requires decided changes for improving energy efficiency. The average total energy consumption in a single-family house in Poland is twice as high as in Germany [9]. Almost $80 \%$ of single-family houses in Poland are heated by heavily exploited, ineffective boilers and coal furnaces. In addition, about $70 \%$ of single-family houses are characterized by a too thin layer of thermal insulation (below $10 \mathrm{~cm}$ ). Considering frequent alarms of smog threat [10] and very bad quality of external air in many Polish cities [11], leads to the conclusion about the need for buildings' energy efficiency improvement in Poland. The main operators of distribution systems in Poland, as part of the fight against smog, introduced anti-smog 
tariffs of the electricity cost purchase [12]. This solution, which worked well in Slovakia and the Czech Republic, should encourage consumers to use electricity while heating their houses. The interest in electrical heating systems has been growing over the last years in Poland [9]. The electricity for heating single-family houses is used mainly in new buildings, constructed after 2007 [13].

This article presents analysis of offshore wind farm potential in electricity production in comparison to typical onshore ones. The power peak demand, energy consumption and load duration curve for a single family houses neighborhood located at the Baltic seaside in Łeba has been analyzed. The neighborhood, consisting of 3 different types of buildings, is modelled with the Energy Plus software [14]. Each building type is characterized by individual working schedules, and heating, ventilation and air conditioning (HVAC) installations. The analysis included the impact of orientation and shading for every building.

\section{Baltic seaside area potential for wind energy production}

In general, we distinguish two possibilities for wind energy production - using onshore or offshore turbines. The major difference between those two is the foundation technology, which is much more complicated for offshore wind turbines. On the other hand, potential of electricity production is much larger for offshore wind farms than for onshore ones.

\subsection{Wind potential in Łeba}

Wind energy potential in the analyzed location - Łeba, is the best all over the country (Fig. 2). In this paper, due to lack of long-term measurement data for Łeba, the wind data was taken from the Typical Meteorological Year (TMY) dataset [14]. In Fig. 3 we can see the hourly value of wind speed. The average wind speed for Łeba is $4.93 \mathrm{~m} / \mathrm{s}$ which is significantly higher than mean speed value for Poland (see section 1).

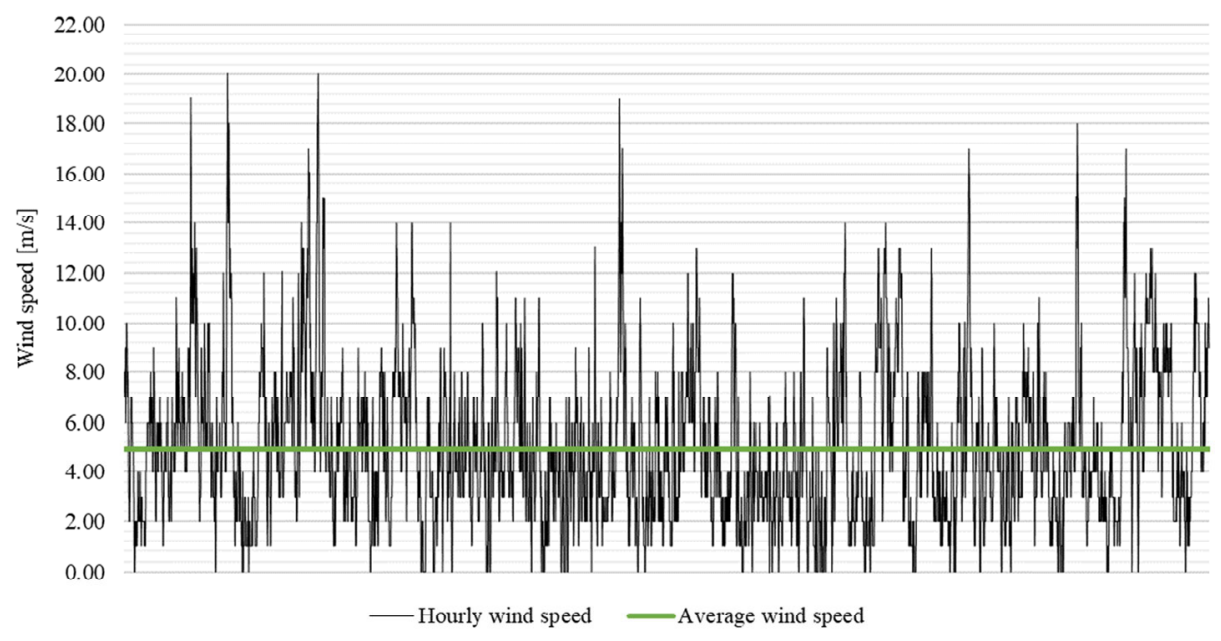

Fig. 3. Wind speed distribution for Łeba according to TMY dataset (own studies). 
The TMY dataset contains information about major wind direction for the analyzed location, as may be observed in Fig. 4 the western and southern wind is dominant. These are the most important climate parameters which should be considered while choosing wind turbine. Referring to Polish conditions, it is necessary to include ambient area when we are planning wind farm construction. According to the Polish regulations [5] one should build a wind turbine at a distance from the nearest building not smaller than 10 times turbine height (including rotor blade). This requirement significantly limits the possibilities for constructing new onshore wind farms in Poland.

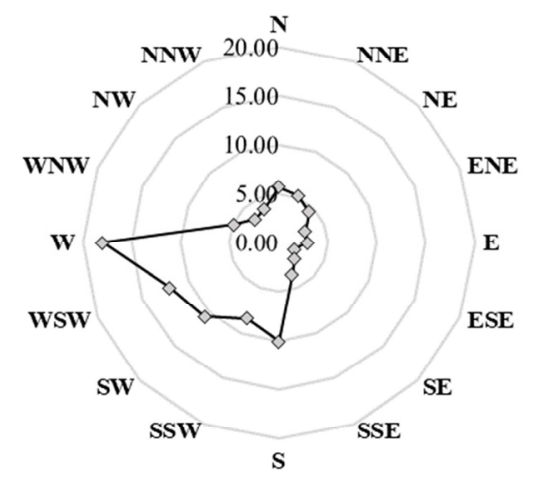

Fig. 4. Wind direction frequency for Łeba according to TMY dataset (own studies).

\subsection{Polish offshore wind potential}

It is well known that wind energy potential is higher offshore than onshore. According to [15] at the end of 2017 global offshore wind farm production reached 17.6 GW capacity while the value of all investments made in this area reached 30 billion Euros. Moreover, it is predicted that by 2030 the offshore wind energy sector will increase more than six times, reaching $115 \mathrm{GW}$ capacity. The Baltic is a very favourable location to allocate wind farms. Nowadays, there are a number of Baltic sea wind farms, especially in Denmark, Sweden and Germany. There are plans to construct more than $12 \mathrm{GW}$ wind farm capacity in the area of the South Baltic Sea [7].

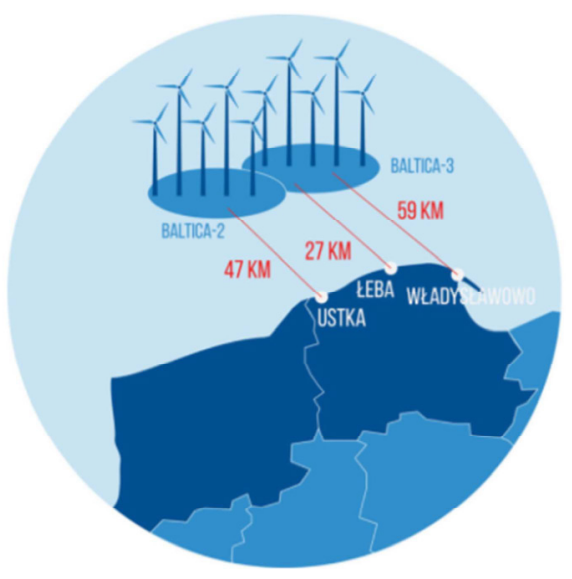

Fig. 5. Location of Baltica 2 and Baltica 3 offshore wind farms in Poland (source: [17]). 
The Polish offshore wind politics assumes constructing the first offshore farm till 2023. Polish Offshore Wind Energy Group predicts that the offshore wind energy will reach even $10 \mathrm{GW}$ capacity by the end of 2040 . There are two main projects concerning offshore wind energy in the Polish Baltic area, Baltica 3 and Baltica 2. Both these projects are in an early planning phase and they are located in a close proximity to the shore (Fig. 5) between Leba and Ustka cities. Baltica 3 [16] assumes 105-131 wind turbines with a 8-10 MW capacity each (specific turbine model is not decided yet). The total project capacity of Baltica 3 is estimated to about $1.05 \mathrm{GW}$. There are only a few pieces of information available about the Baltica 2 project [17]. Baltica 2 total capacity is assumed around $1.2 \mathrm{GW}$ with no turbine model and number selected yet.

There are three main aspects which should be considered while constructing an offshore wind farm [18]. The first one is depth of the sea- when the depth is greater, the cost of the turbine foundation is higher. According to [16] the depth range for Baltica 3 and Baltica 2 is between $20-50 \mathrm{~m}$ which characterizes these locations as profitable for wind farms. The second aspect is distance from the shore - the further from the land, the higher the costs of transmission and installation [18]. The third aspect is wind energy potential of a chosen localization. The energy potential is strictly related to the climate conditions of the analyzed area. There are only few research platforms in the Baltic Sea which are gathering offshore climate data. One of the most technologically advanced is the research platform FINO 2 [19] which is located 33km north of the island Rugen (Germany). PGE Energia Odnawialna (Polish energy contractor) started a campaign of measuring wind conditions on the Baltic Sea using a floating lidar. The equipment is placed in the planned area for Baltica 3. Till now there is no wind conditions database for the Polish Baltic Sea region. The power of wind energy is proportional to the wind speed up to the power of 3 . According to $[18,20,21]$ the Baltic average wind speed, about $50 \mathrm{~km}$ distance from the shore, is around $9 \mathrm{~m} / \mathrm{s}$ at $100 \mathrm{~m}$ height above sea level. In Fig. 6 we can see a histogram of wind speed distribution at 102 meters height above sea level measured in 2015 by the FINO2 research platform $[22,23]$. The average wind speed measured at FINO2 platform is $9.74 \mathrm{~m} / \mathrm{s}$ (in 2015) which is much higher than mean speed value for Łeba (see Fig. 3).

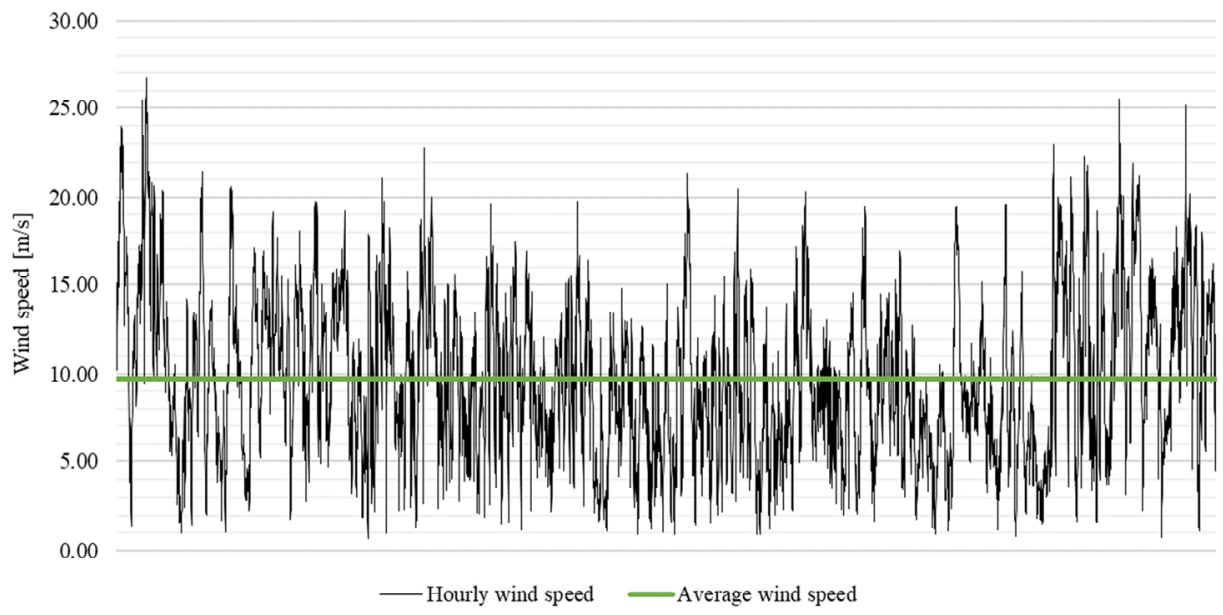

Fig. 6. Wind speed distribution histogram for data measured at 102 meters height at the FINO 2 research platform in 2015. 


\subsection{Polish offshore wind potential}

The wind turbine power calculations [24] can be made using equation (1). As can be seen, the potential of electrical power production by a wind farm depends on the turbine geometry, wind speed and power coefficient - which is unique to each turbine type and is a function of wind speed that the turbine is operating with. Based on Betz's law, it is known that wind turbine can convert only $59.3 \%$ of the wind kinetic energy into mechanical energy. According to the Betz theoretical limit of the maximum power coefficient is 0.59 . In fact, there are some factors causing its decline, i.a. rotation of the wake behind the rotor or aerodynamic drag [24]. Usually the value of the $C_{p}$ coefficient is in the range between 0.35 and 0.45 . Moreover, while making wind energy potential calculations, the wind speed should be converted to the value at wind turbine rotor level using equation (2).

$$
\begin{gathered}
P_{\text {avail }}=\frac{1}{2} \rho A V^{3} C_{p} \\
V_{h}=V_{0}\left(\frac{h}{h_{0}}\right)^{\alpha}
\end{gathered}
$$

where:

$P_{\text {avail }}$ - available power [MW],

$\rho$ - air density $\left[\mathrm{kg} / \mathrm{m}^{3}\right]$,

$A$ - the swept area of the turbine $\left[\mathrm{m}^{2}\right]$,

$V$ - wind speed $[\mathrm{m} / \mathrm{s}]$,

$C_{p}$ - power coefficient [-],

$V_{h}-$ wind speed at rotor level $[\mathrm{m} / \mathrm{s}]$,

$V_{0}-$ wind speed at measurement height $[\mathrm{m} / \mathrm{s}]$,

$h$ - rotor height $[\mathrm{m}]$,

$h_{0}$ - measurement height [m],

$\alpha$ - area roughness coefficient [-].

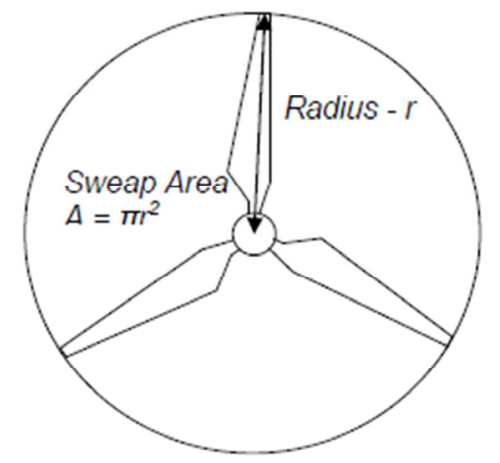

Fig. 7. The swept area of the turbine(source: [24]). 


\subsection{Wind turbines characteristics}

In this article two types of wind turbines were considered. The first one was selected as a typical onshore wind turbine for the Polish conditions (i.e. the same as in the onshore wind farm located in Puck, total capacity 22MW). The second one (offshore turbine) was chosen as one which might be used in Baltica 3 project. Both turbine parameters are set in Table 1.

Table 1. Technical parameters comparison of the analyzed wind turbines.

\begin{tabular}{|l|c|c|}
\hline \multirow{2}{*}{\multicolumn{1}{|c|}{ Datasheet }} & \multicolumn{2}{c|}{ Turbine model } \\
\cline { 2 - 3 } & V164-8.0 & Ge 1.6-100 \\
\hline Company & Vestas & General Electric \\
\hline Destiny & offshore & Onshore \\
\hline Rated power $[\mathbf{k W}]$ & 8000 & 1600 \\
\hline Hub height $[\mathbf{m}]$ & 100 & 100 \\
\hline Rotor diameter $[\mathbf{m}]$ & 164 & 100 \\
\hline Swept area $\left[\mathbf{m}^{\mathbf{2}}\right]$ & 21124.0 & 7854.0 \\
\hline Cut-in wind speed $[\mathbf{m} / \mathbf{s}]$ & 4.0 & 3.5 \\
\hline Rated wind speed $[\mathbf{m} / \mathbf{s}]$ & 13.0 & 11.0 \\
\hline Cut-out wind speed $[\mathbf{m} / \mathbf{s}]$ & 25.0 & 25.0 \\
\hline Survival wind speed $[\mathbf{m} / \mathbf{s}]$ & 50.0 & no data \\
\hline
\end{tabular}

The most important parameter for wind energy calculations is power curve with power coefficient $\left(C_{p}\right)$ distribution. In Fig. 8 the power $(\mathrm{P})$ and power coefficient $\left(C_{p}\right)$ are compared for the two turbines which are selected for the analysis.

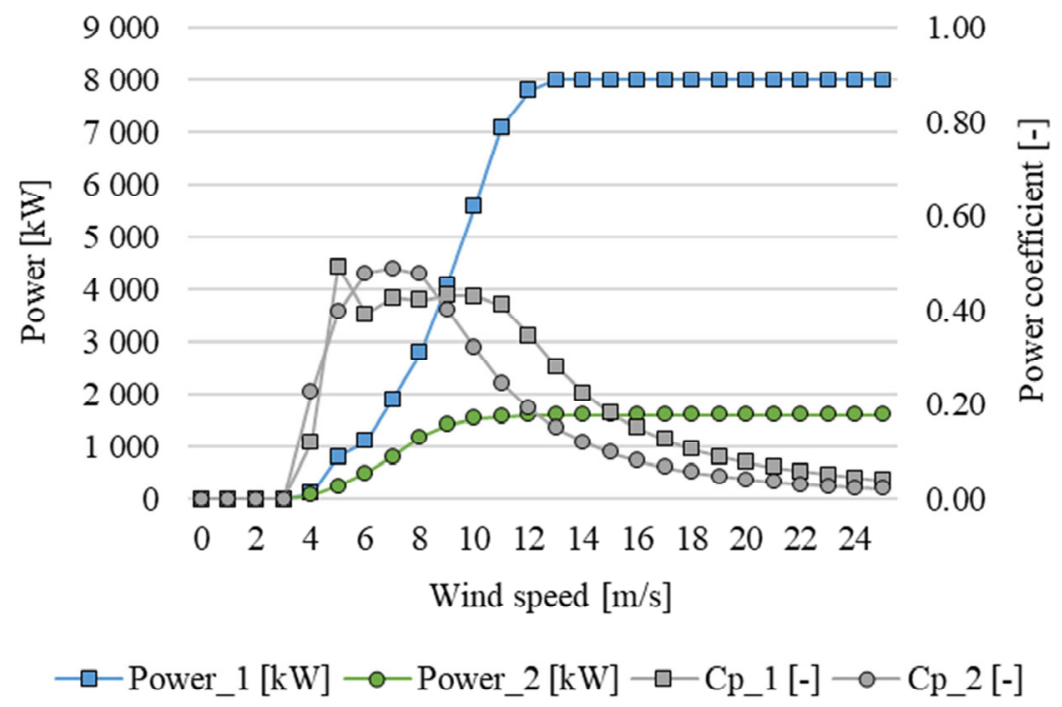

Fig. 8. Power curve for selected wind turbines (source: [16]). 


\section{Description of a single-family housing neighbourhood}

In this article an electrically powered single-family neighborhood was analyzed. The neighborhood was assumed to consist of three types of single-family houses, built in 2017 (Fig. 11), 2014 (Fig. 12) and 2010 (Fig. 13). Each building was characterized by thermal parameters in accordance with the Polish technical requirements [25, 26]. For the buildings constructed in 2010 and 2014 natural ventilation was assumed, while for the 2017 buildings a mechanical ventilation with heat recovery was set. Electric floor heating in bathrooms and convectors were assumed as heating system in all buildings. LED lighting was assumed in all buildings. Additionally, an air conditioning system (fan-coil units) was considered in the 2014 and 2017 buildings.

The share of individual buildings types was assumed according to the Polish statistical data [27]. The number of individual houses (Fig. 9) was calculated according to the housing construction report for each year between 2010 and 2017 and considering the statistical data for single-family houses with electric heating [28].

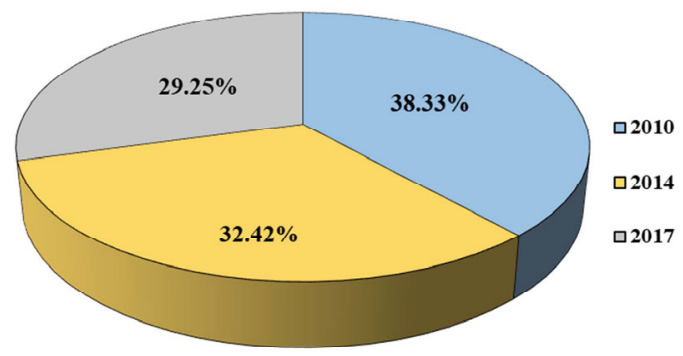

Fig. 9. Share of single-family houses with electric heating system created in 2010, 2014 and 2017 in Poland.

In the analysis the orientation of individual buildings (related to the 8 main world directions) was included. In addition, for each building solar radiation impact was reduced due to the shading from the nearest area (Fig. 10). It was assumed that the plot of each building is a $25 \times 25 \mathrm{~m}$ square plan. The whole neighborhood occupied the square plan area of $62,500 \mathrm{~m}^{2}$ (10 houses in each row and column). The analysis contains results for a neighborhood consisting of 100 single-family buildings (containing 38 houses built in 2010, 33 built in 2014 and 29 built in 2017). The shading scheme generated from the surrounding area of each object was adopted in accordance with the neighborhood buildings arrangement. The selection of the orientation of individual objects is random. 


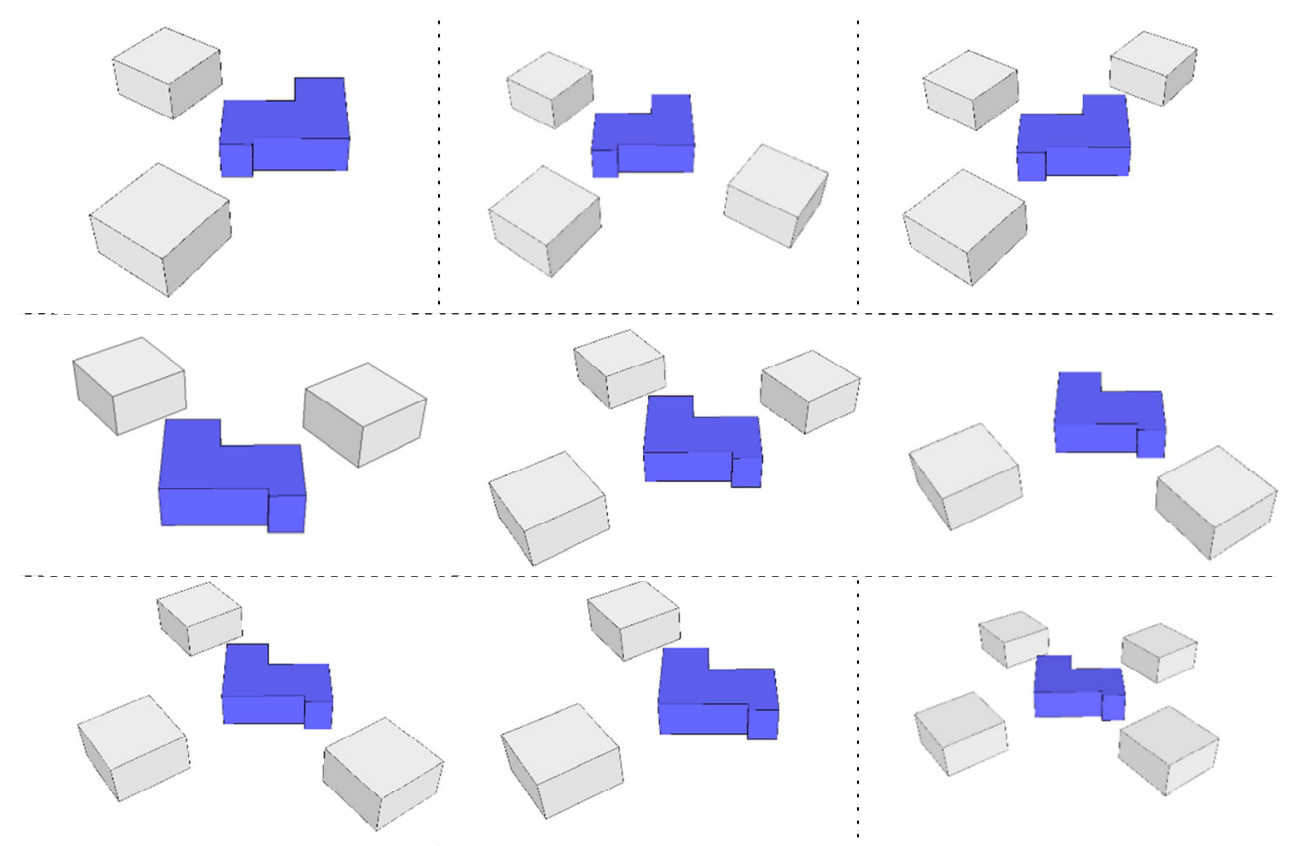

Fig. 10. All schemes of nearest area of the analyzed building considered in the simulations.

Moreover, in the analysis it was assumed that each family has 4 members. The work schedule of each building assumed going out (work, school) from 8 a.m. to 4 p.m. and weekends as a non-working days. Heating system temperature reduction was adopted for periods when building is empty (in order to reduce energy consumption). In the analysis the residents sleep hours was set from 11p.m. to 7 a.m.
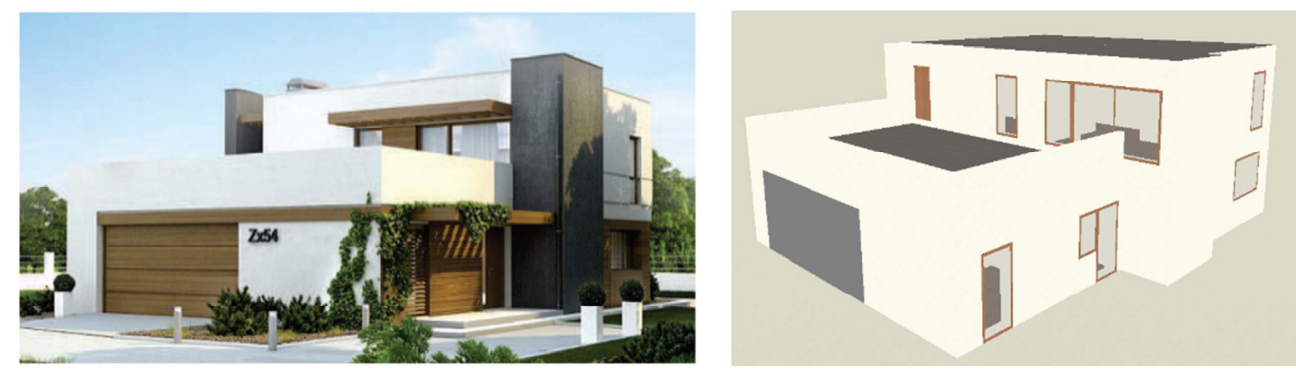

Fig. 11. Visualization of the 2017 building from the design project (left) and modeled with Design Builder software (right).
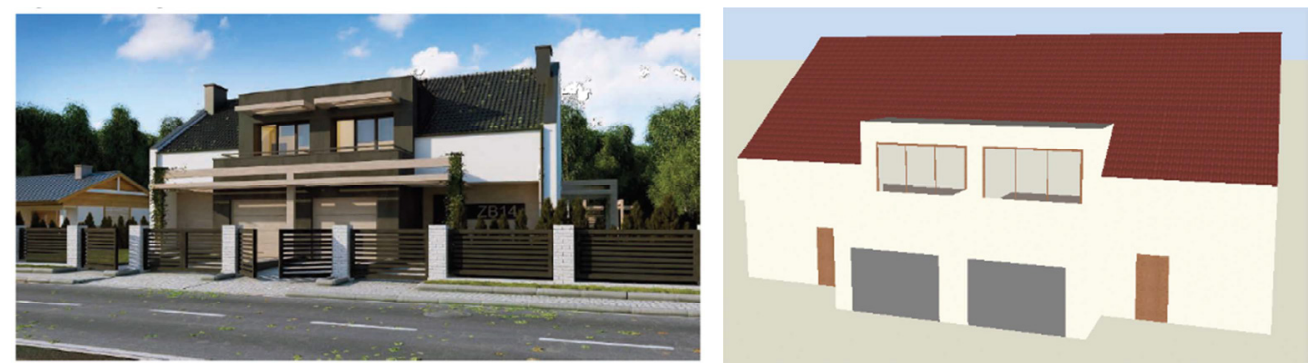

Fig. 12. Visualization of the 2014 building from the design project (left) and modeled with Design Builder software (right). 


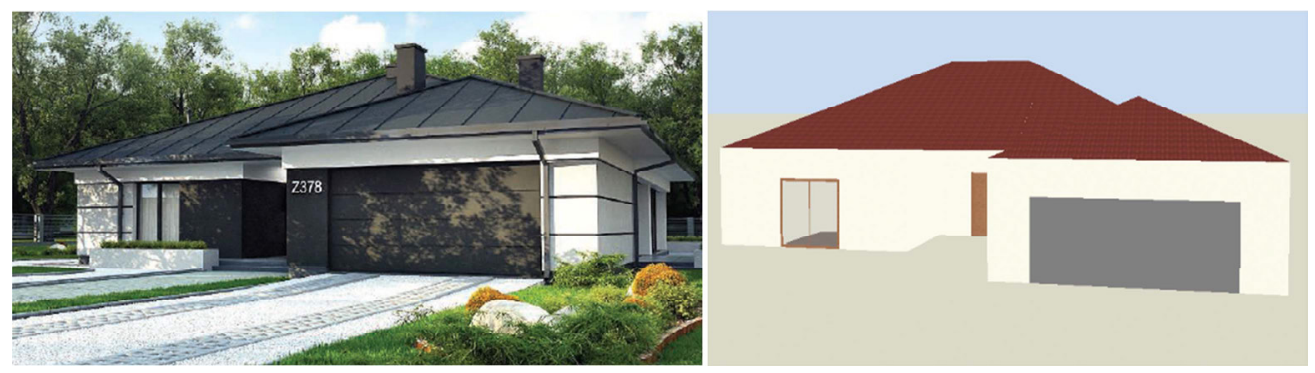

Fig. 13. Visualization of the 2010 building from the design project (left) and modeled with Design Builder software (right).

\section{Analysis results}

The simulations' results contain the power demand for each load type and total electricity consumption for every single building in the analyzed area. In Fig. 14 the percentage share of electricity consumption for each house type is presented for the base variant. The latter one assumed analysis of a single building without nearest surroundings which generate shading.
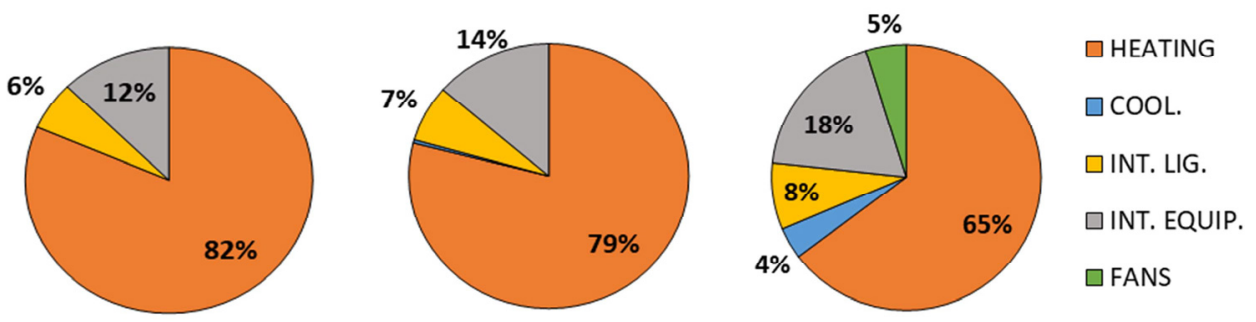

Fig. 14. Percentage share of electricity consumption for 2010 (left), 2014 (middle) and 2017 (right) houses.

The whole analyzed neighborhood of single-family houses consisted of 100 buildings in different orientations and the nearest area variants (see section 3). In total, 219 simulations were made in order to reliably assess the energy consumption of the analyzed area. In Fig. 15 the load duration curve for the neighborhood is presented. The highest electricity load demand is $1,543.42 \mathrm{~kW}$.

The analysis included calculations of potential power production by the selected onshore and offshore wind turbines. Assuming the adopted wind turbine types (see subsection 2.4.) and the average annual wind speed (see subsection 2.1.) it was calculated that to cover the peak load for the analyzed neighborhood it is necessary to have at least seven onshore or only one offshore wind turbine. 


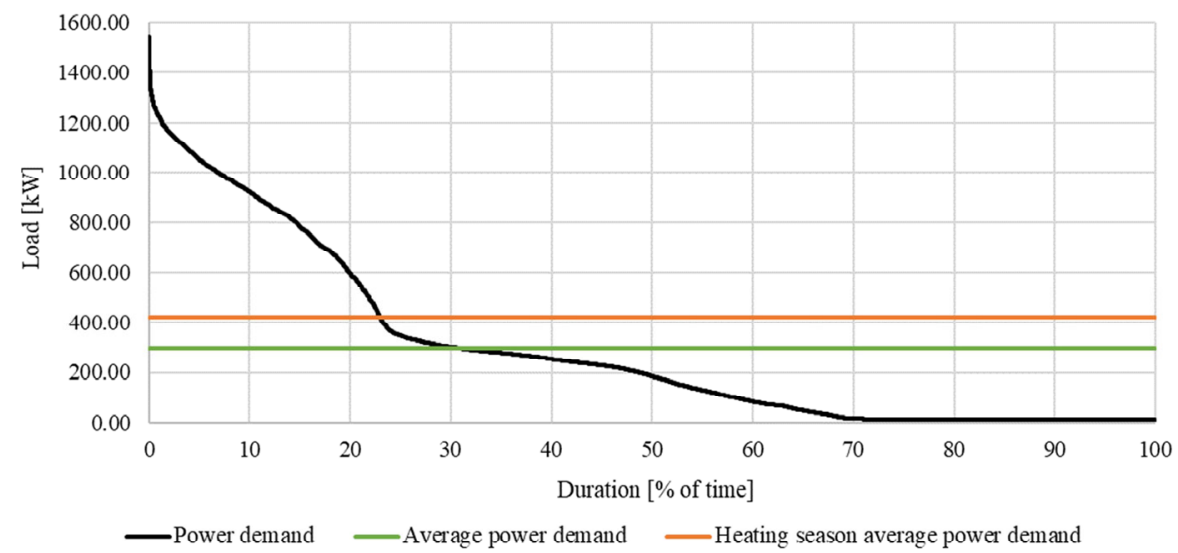

Fig. 15. Load duration curve for the analyzed single-family houses neighborhood located in Łeba.

\section{Conclusions}

The main purpose of this article was to show the potential for using offshore wind energy to supply electricity for the housing sector. This is a part of the development plans for renewable energy systems in Poland.

As shown by the analysis, application of the offshore wind farms has a significant potential for generating electricity. It results from the fact of better technical parameters of the offshore wind turbines than the onshore ones, as well as more favorable climatic conditions at the sea than on the land. The Polish Baltic Sea areas are characterized by much higher wind speed than the coastal areas, which effectively increases the potential for electricity production by offshore wind farms.

The use of offshore wind farms is also recommended due to the shape and the depth of the Baltic seabed and the Polish wind energy regulations regarding the deployment of onshore wind turbines distribution.

The analysis used the simulations' results obtained for a hypothetical single-family houses neighborhood estate of 100 objects built in years 2010, 2014 and 2017, which are fully powered by electricity. The calculations results confirmed the superiority of offshore wind farms. According to the obtained results of calculations, it can be estimated that the planned offshore wind farm Baltica 3 will be able to supply electricity for over 34 thousand single family houses (the worst scenario based on the data described in this paper).

Energy production by wind farms is dependent on the stochastic climatic factors and thus it cannot be precisely forecasted both for long and short term periods. Due to that, there is a possible lack of ability to cover the electrical energy demand by wind farms.

This analysis did not include some aspects related to energy distribution (the amount of losses in transmission). In addition, no economic analysis concerning the use of the wind turbines has been carried out.

\section{References}

1. European Commission, Energy Efficiency Plan 2011, Brussels (2011)

2. European Commission, A Roadmap for moving to a competitive low carbon economy in 2050, Brussels (2011)

3. Renewables 2017, Global Status Reporting. Renewable Energy Policy Network for the 21st Century (2018) 
4. Lorenc H., Struktura i zasoby energetyczne wiatru w Polsce, (IMiGW, Warszawa 1996)

5. Ustawa z dnia 20 maja 2016r. o inwestycjach w zakresie elektrowni wiatrowych.

6. M.J. Dvorak, B.A. Corcoran, J.E. Ten Hoeve, N.G. Mclntyre, M.Z. Jacobson, U.S. East Coast offshore wind energy resources and their relationship to peak-time electricity demand, Wind Energy (2012)

7. C.B. Hasager, J. Badger, F. Bingol, N.E. Clausen, A.N. Hahmann, I. Karagali, M. Badger, A.P. Diaz, Wind Energy Resources of the South Baltic Sea, World Renewable Energy Congress - Sweden (2011)

8. Narodowa Agencja Poszanowania Energii SA, Polish building typology - Scientific Report, Warsaw (2012)

9. Instytut Ekonomii Środowiska, Efektywność Energetyczna w Polsce - Przegląd 2015, Kraków (2016)

10. http://airindex.eea.europa.eu \{access: 12.04.2018r.

11. European Environment Agency, Air quality in Europe - 2017 report, Luxemburg (2017)

12. https://www.gkpge.pl/Oferta/Dla-domu/Regionalna/Oferta-antysmogowa \{access: $14.03 .2018 \mathrm{r}$.

13. Central Statistical Office, Energy Consumption in Households in 2015, Warsaw (2017)

14. https://energyplus.net \{access: 10.02.2018r.\}

15. https://www.bloomberg.com/europe \{access: 01.03.2018r.

16. http://www.4coffshore.com \{access: 01.03.2018r.\}

17. http://mfwbaltica.pl/projekt.html \{access: 20.03.2018r.\}

18. S. Cavazzi, A.G. Dutton, An Offshore Wind Energy Geographic Information System (OWE-GIS) for assessment of the UK's offshore wind energy potential, Renewable Energy (2015)

19. http://www.fino2.de/en/ \{access: 01.03.2018r.

20. A. Chaouachi, C.F. Covrig, M. Ardelean, Multi-criteria selection of offshore wind farms: Case study for the Baltic States, Energy Policy (2017)

21. C.B. Hasager, M. Badger, A. Pena, X. G. Larsen, F. Biangol, SAR-Based Wind Resource Statistics in Baltic Sea, Remote Sensing (2011)

22. https://www.bmwi.de/ \{access: 01.03.2018r.\}

23. https://www.ptj.de \{access: 01.03.2018r.\}

24. J.F. Manwell, J.G. McGowan, A.L. Rogers, Wind Energy Explained: Theory, Design and Application (2011)

25. Rozporządzenie Ministra Infrastruktury $\mathrm{z}$ dnia 6 listopada 2008r. zmieniające rozporządzenie w sprawie warunków technicznym, jakim powinny odpowiadać budynki i ich usytuowanie

26. Rozporządzenie Ministra Infrastruktury $\mathrm{z}$ dnia 14 listopada 2017r. zmieniające rozporządzenie w sprawie warunków technicznym, jakim powinny odpowiadać budynki i ich usytuowanie

27. https://stat.gov.pl/en/ \{access: 01.03.2018r.

28. Central Statistical Office, Energy Consumption in Households in 2017, Warsaw (2017) 